\title{
บUsisersily
}

\section{ETHANOL PRODUCTION FROM SUGARCANE BAGASSE USING SSF PROCESS AND THERMOTOLERANT YEAST}

Silva, G. M., Giordano, R. L. C., Cruz, A. J. G., Ramachandriya, K. D., Banat, I., \& Wilkins, M. R. (2015).

ETHANOL PRODUCTION FROM SUGARCANE BAGASSE USING SSF PROCESS AND THERMOTOLERANT YEAST. Transactions of the ASABE, 58(2), 193-200.

https://www.researchgate.net/publication/281940799_Ethanol_production_from_sugarcane_bagasse_using_SSF _process_and_thermotolerant_yeast

Link to publication record in Ulster University Research Portal

\section{Published in:}

Transactions of the ASABE

Publication Status:

Published (in print/issue): 01/01/2015

\section{Document Version}

Publisher's PDF, also known as Version of record

\section{General rights}

Copyright for the publications made accessible via Ulster University's Research Portal is retained by the author(s) and / or other copyright owners and it is a condition of accessing these publications that users recognise and abide by the legal requirements associated with these rights.

\section{Take down policy}

The Research Portal is Ulster University's institutional repository that provides access to Ulster's research outputs. Every effort has been made to ensure that content in the Research Portal does not infringe any person's rights, or applicable UK laws. If you discover content in the Research Portal that you believe breaches copyright or violates any law, please contact pure-support@ulster.ac.uk. 


\title{
ETHANOL PRODUCTION FROM SUGARCANE BAGASSE USING SSF PROCESS AND THERMOTOLERANT YEAST
}

\author{
G. M. Silva, R. L. C. Giordano, A. J. G. Cruz, K. D. Ramachandriya, I. M. Banat, M. R. Wilkins
}

\begin{abstract}
Sugarcane bagasse (SCB) pretreated by hydrothermolysis at $195^{\circ} \mathrm{C}$ for 10 min was used as a substrate for ethanol production in a simultaneous saccharification and fermentation (SSF) process with the thermotolerant yeast Kluyveromyces marxianus IMB 3 at $45^{\circ} \mathrm{C}$. SSF was carried out for 7 days using 15 and 30 filter paper units (FPU) cellulase $g^{-1}$ treated SCB (Accellerase 1500) to determine the effect of enzyme loading on ethanol production. Different pretreated dry solids loadings of $10 \%$ and $15 \%(w / w)$ were investigated in this work during enzymatic hydrolysis. Results showed $89.7 \%$ hemicellulose removal during pretreatment and glucan recovery of $97.8 \%$. The highest ethanol concentration of $29.2 \mathrm{~g} \mathrm{~L}^{-1}$ was obtained with 30 FPU cellulase $\mathrm{g}^{-1}$ treated SCB within $72 \mathrm{~h}$, which was equivalent to $58.9 \%$ of the maximum theoretical ethanol yield.
\end{abstract}

Keywords. Enzymatic hydrolysis, Ethanol, Hydrothermolysis, Kluyveromyces marxianus IMB3, SSF, Sugarcane bagasse.

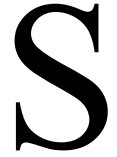
ugarcane bagasse $(\mathrm{SCB})$ is a lignocellulosic material widely found in Brazil, particularly in the southeast of the country. SCB has been investigated by scientists in Brazil as a potential source for ethanol production (da Silva et al., 2010; Rocha et al., 2011; Rocha et al., 2012; Santos et al., 2012). In Brazil, every ton of ground sugarcane used for producing sugar and ethanol generates, on average, $250 \mathrm{~kg}$ of bagasse and $200 \mathrm{~kg}$ of sugarcane straw (UNICA, 2012). During the 2013-2014 Brazilian harvest, more than 658 million tons of sugarcane was ground, which generated about 165 million tons of bagasse and 132 million tons of sugarcane straw (CONAB, 2014). Currently, bagasse can be used in several applications, such as energy cogeneration and production of ethanol and animal feed (Rocha et al., 2012). Economical and environmentally beneficial uses of SCB are greatly desired.

SCB as well as other types of lignocellulosic biomass primarily consist of cellulose, hemicellulose, and lignin; however, the composition of each component varies with the raw material. Cellulose is a natural polymer consisting

Submitted for review in October 2014 as manuscript number ES 11024; approved for publication by the Energy Systems Community of ASABE in January 2015.

The authors are Gislene Mota da Silva, Graduate Student, Raquel de Lima Camargo Giordano, Professor and Antonio José Gonçalves da Cruz, Associate Professor, Department of Chemical Engineering, Federal University of Sao Carlos, Sao Paulo, Brazil; Karthikeyan D. Ramachandriya, ASABE Member, Former Graduate Associate, Department of Biosystems and Agricultural Engineering, Oklahoma State University, Stillwater, Oklahoma; Ibrahim M. Banat, Professor, School of Biomedical Sciences, University of Ulster, Coleraine, Northern Ireland; Mark R. Wilkins, ASABE Member, Associate Professor, Department of Biosystems and Agricultural Engineering, Oklahoma State University, Stillwater, Oklahoma. Corresponding author: Antonio J. G. Cruz, Department of Chemical Engineering, Federal University of Sao Carlos, Via Washington Luis (SP 310), $\mathrm{km} 235$, P.O. Box 676, CEP 13565-905, Sao Carlos, SP, Brazil; phone: +55-16-3351-8002; e-mail: ajgcruz@ufscar.br. of cellobiose units linked by glycosidic linkages of the type $\beta-(1 \rightarrow 4)$ (Fengel and Wegener, 1989). Hemicelluloses are polysaccharides that are closely associated with cellulose in the plant cell wall. They consist of polymers of several pentoses (xylose and arabinose), hexoses (glucose, mannose, and galactose), and uronic acids. Lignin is a highly branched material that can be classified as a polyphenol constituting an irregular arrangement of several phenylpropane units (Silva et al., 2009). Lignin plays an important role in cell wall structure as an agent of protection against microbial damage. Cellulose and hemicellulose are not directly available for bioconversion due to their intimate association with lignin (Trajano et al., 2013; Williams and Morrison, 1982).

Ethanol production from lignocellulosic biomass consists of four steps: pretreatment, enzymatic hydrolysis, fermentation, and distillation. Pretreatment decreases the crystallinity of cellulose, removes hemicelluloses, and increases the surface area of the available biomass. Pretreatment is an important step for increasing the accessibility of cellulose to enzymes during enzymatic hydrolysis. Hydrolysis is the conversion of carbohydrate polymers into monomeric sugars (Mosier et al., 2005). These sugars are converted to ethanol by fermenting microorganisms. Finally, distillation is used to concentrate and purify the ethanol.

A great number of pretreatment methods have been studied in the bioconversion of biomass, and among them is hydrothermolysis. This pretreatment (also known as hydrothermal pretreatment, autohydrolysis, aquasolv, or liquid hot water pretreatment) can be considered an eco-friendly processing technology since it uses only water as a solvent, which reduces corrosion problems and the formation of toxic compounds while providing a high recovery of hemicellulose and making cellulose more accessible to cellulases (Perez et al., 2008; Pessani et al., 2011; Ruiz et al., 2012; Saha et al., 2013; Yu et al., 2013).

Cellulosic biomass can be converted to ethanol using dif- 
ferent processes, one of which is simultaneous saccharification and fermentation (SSF). SSF has been intensely investigated because it reduces contamination risk and lowers costs through the usage of the same reactor for hydrolysis and fermentation (Garcia-Aparicio et al., 2011; Ruiz et al., 2012). SSF combines enzymatic hydrolysis of cellulose with simultaneous fermentation of the sugars to ethanol, thereby alleviating problems caused by product inhibition (Olofsson et al., 2008; Wingren et al., 2003). Other processes have also been reported for ethanol production from lignocellulosic materials, including separate hydrolysis and fermentation (SHF), simultaneous saccharification and co-fermentation (SSCF), and presaccharification prior to simultaneous saccharification and fermentation (PSSF) (Garcia-Aparicio et al., 2011; Pessani et al., 2011). PSSF has been recently reported by Moreno et al. (2013) using the thermotolerant yeast Kluyveromyces marxianus CECT 10875.

K. marxianus IMB strains were isolated by Banat et al. (1992) from a wine distillery in India. These IMB yeast strains were capable of growing and producing relatively high ethanol concentrations at temperatures between $40^{\circ} \mathrm{C}$ and $50^{\circ} \mathrm{C}$. Barron et al. (1995) reported that $K$. marxianus IMB3 was capable of ethanol production at $45^{\circ} \mathrm{C}$ on media containing milled paper and exogenously added commercial cellulose. Suryawati et al. (2008, 2009) reported the production of ethanol by $K$. marxianus $\mathrm{IMB} 4$ at $45^{\circ} \mathrm{C}$ using switchgrass pretreated by hydrothermolysis and SSF. One comparative study between $K$. marxianus IMB strains and Saccharomyces cerevisiae $\mathrm{D}_{5} \mathrm{~A}$ in SSF with switchgrass pretreated by hydrothermolysis showed similar ethanol production yields for $K$. marxianus IMB3 at $45^{\circ} \mathrm{C}$ and S. cerevisiae $\mathrm{D}_{5} \mathrm{~A}$ at $37^{\circ} \mathrm{C}$ (Faga et al., 2010). The IMB3 strain was also used to produce ethanol at different cellulase loadings ( 0.1 to $1.1 \mathrm{~mL} \mathrm{~g}^{-1}$ glucan), with the greatest ethanol yield ( $86 \%$ of maximum theoretical) achieved with $0.7 \mathrm{~mL} \mathrm{~g}^{-1}$ glucan using $8 \%$ switchgrass pretreated by hydrothermolysis in batch SSF (Pessani et al., 2011). Kadar et al. (2004) investigated the use of various industrial wastes (Solka Floc 200, old corrugated cardboard, waste cardboard, and paper sludge) in SSF using $K$. marxianus (Y01070) and $S$. cerevisiae (commercial strain) to produce ethanol. After $72 \mathrm{~h}$, the ethanol concentrations were 17.8 and $16.6 \mathrm{~g} \mathrm{~L}^{-1}$ and the volumetric ethanol productivities were 0.25 and $0.23 \mathrm{~g} \mathrm{~L}^{-1} \mathrm{~h}^{-1}$, respectively, for $K$. marxianus and $S$. cerevisiae. SCB was employed in experiments to produce ethanol with thermotolerant $S$. cerevisiae UFPEDA 1238 (Santos et al., 2012). The substrate was pretreated by steam explosion and then delignified with sodium hydroxide. PSSF experiments ( $6 \mathrm{~h}$ of prehydrolysis) were carried out at $37^{\circ} \mathrm{C}$ using $8 \%$ dry solids loading with $20 \mathrm{FPU} \mathrm{g}{ }^{-1}$ cellulose and $10 \% \mathrm{v} / \mathrm{v} \beta$-glucosidase. After $30 \mathrm{~h}, 25 \mathrm{~g} \mathrm{~L}^{-1}$ of ethanol and a $0.70 \mathrm{~g} \mathrm{~L}^{-1} \mathrm{~h}^{-1}$ ethanol volumetric productivity were obtained.

In this context, the present work investigated the use of hydrothermolysis-pretreated SCB as substrate for ethanol production using SSF. The effects of dry solids content (10\% and $15 \%, \mathrm{w} / \mathrm{w})$ and enzyme loading (15 FPU g ${ }^{-1} \mathrm{SCB}$ and $30 \mathrm{FPU} \mathrm{g}^{-1} \mathrm{SCB}$ ) on ethanol yields were evaluated. The thermotolerant yeast $K$. marxianus IMB3 was employed throughout this work.

\section{Methods ANd Materials \\ SAMPLE PREPARATION}

The SCB used in this work was supplied by Centro de Tecnologia Canavieira (Piracicaba, Sao Paulo, Brazil). The biomass was ground through a $2 \mathrm{~mm}$ screen using a Thomas-Wiley mill (Arthur H. Thomas Co., Philadelphia, Pa.). The ground SCB was stored in reusable bags at room temperature prior to pretreatments. The polysaccharide, lignin, ash, and extractives contents of the biomass were determined before and after pretreatment using a standard procedure developed by the National Renewable Energy Laboratory (NREL) (Sluiter et al., 2011).

\section{HYDROTHERMOLYSIS}

SCB samples were pretreated by hydrothermolysis in a $1 \mathrm{~L}$ benchtop pressure reactor (Series 4250, Parr Instrument Co., Moline, Ill.) equipped with a propeller agitator, heater, and temperature controller. The reactor was first filled with $60 \mathrm{~g}$ of dry SCB. Moisture content of the SCB (6.7\%) was determined by the method of Sluiter et al. (2008a). Deionized water was then added to achieve a $10 \%$ dry solids mixture. The completely sealed reactor was heated to $195^{\circ} \mathrm{C}$ and agitated at $200 \mathrm{rpm}$. The temperature was held at $195^{\circ} \mathrm{C}$ for $10 \mathrm{~min}$. After heating was complete, the reactor was cooled in an ice bath to a temperature of $40^{\circ} \mathrm{C}$. The solid and liquid fractions were separated by vacuum filtration through Whatman \#5 filter paper. The solids were rinsed with $600 \mathrm{~mL}$ of deionized water at $60^{\circ} \mathrm{C}$ three times to remove any residual soluble sugars and/or fermentation inhibitors. A 5 to $6 \mathrm{~g}$ sample of the washed residual solids was dried in an oven for $24 \mathrm{~h}$ at $105^{\circ} \mathrm{C}$ to determine the mass of dry solids recovered after pretreatment (Sluiter et al., 2008a). The solids were stored in sealed plastic bags at $4^{\circ} \mathrm{C}$ until they were used for enzymatic hydrolysis.

SCB was extracted prior to pretreatment by ethanol followed by deionized water using a Dionex accelerated solvent extractor (model 300, Dionex Corp., Sunnyvale, Cal.) and a standard NREL procedure (Sluiter et al., 2008c). Removal of ethanol from extractives was done using a RapidVap N2 evaporation system (Labconco Corp., Kansas City, Kans.) at $500 \mathrm{mbar}$ and $40^{\circ} \mathrm{C}$ for $24 \mathrm{~h}$. Waterextractives samples were evaporated in an oven at $40^{\circ} \mathrm{C}$ for $48 \mathrm{~h}$. Pretreated samples were not extracted.

The composition of degradation products in the prehydrolysate was determined using a standard NREL procedure (Sluiter et al., 2008b). Analyses of carbohydrates and organic acids were carried out using HPLC with refractive index detection (RID) (Agilent 1100 Series, Santa Clara, Cal.) on an Aminex HPX-87P column (BioRad, Sunnyvale, Cal.) at $85^{\circ} \mathrm{C}$ with deionized water as eluent flowing at $0.6 \mathrm{~mL} \mathrm{~min}^{-1}$.

\section{Microorganism AND GrowTH Conditions}

Cultures of $K$. marxianus IMB3 were obtained from the University of Ulster (Coleraine, Northern Ireland) and were grown on liquid yeast peptone dextrose (YPD) medium containing $\left(\mathrm{g} \mathrm{L}^{-1}\right)$ : 10.0 yeast extract, 20.0 peptone, and 50.0 glucose. A loopful of $K$. marxianus IMB3 cells were aseptically transferred into $250 \mathrm{~mL}$ baffled culture flasks 
containing $100 \mathrm{~mL}$ of YPD medium covered with aerobic stoppers (Bug Stopper, Whatman PLC, Florham Park, N.J.). Flasks were incubated at $45^{\circ} \mathrm{C}$ for $17 \mathrm{~h}$ at $200 \mathrm{rpm}$ on an orbital shaker (MaxQ mini 4450, Thermo Scientific, Dubuque, Iowa). The cells were collected by centrifugation at $7200 \times g$ for $6 \mathrm{~min}$ (Sorvall Legend RT, Thermo Scientific, Waltham, Mass.). The supernatant was decanted, and the cells were washed twice in $0.89 \%(\mathrm{w} / \mathrm{v})$ sterile sodium chloride $(\mathrm{NaCl})$ solution (Ramachandriya et al., 2013). The obtained cells were resuspended in $0.89 \%(\mathrm{w} / \mathrm{v})$ sterile $\mathrm{NaCl}$ solution to give an optical density (OD) of 5.0.

\section{SimultaneOUS SACCHARIFICATION AND FERMENTATION (SSF)}

Yeast fermentation medium (YFM) was prepared using DI water consisting of $\left(\mathrm{g} \mathrm{L}^{-1}\right)$ : 5.0 yeast extract, 20.0

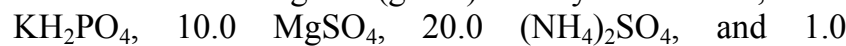
$\mathrm{MnSO}_{4} \cdot \mathrm{H}_{2} \mathrm{O}$ (Banat et al., 1992). Commercial cellulase (Accellerase 1500, kindly provided by Dupont Genencor, Palo Alto, Cal.) with activity of 99.6 FPU $\mathrm{mL}^{-1}$, was used in the SSF experiments. Cellulase activity was determined using a standard filter paper assay (Ghose, 1987).

SSF was conducted in $250 \mathrm{~mL}$ baffled flasks sealed with rubber stoppers fitted with a one-way air valves (check valve, Fisher Scientific, Pittsburgh, Pa.) to maintain an anaerobic environment. In this study, four conditions were tested:

- 15 FPU cellulase $\mathrm{g}^{-1}$ pretreated dry $\mathrm{SCB} / 10 \%(\mathrm{w} / \mathrm{w})$ dry SCB loading.

- 30 FPU cellulase $\mathrm{g}^{-1}$ pretreated dry SCB/10\% (w/w) dry SCB loading.

- 15 FPU cellulase $\mathrm{g}^{-1}$ pretreated dry SCB/15\% (w/w) dry SCB loading.

- 30 FPU cellulase $\mathrm{g}^{-1}$ pretreated dry SCB/15\% (w/w) dry SCB loading.

Each fermentation flask contained $5.0 \mathrm{~mL}$ of 10X YFM, $2.5 \mathrm{~mL}$ of $1 \mathrm{M}$ sodium citrate buffer at $\mathrm{pH} 5.5,0.5 \mathrm{~mL}$ of concentrated $K$. marxianus IMB3 culture (OD 5.0), 10 or $15 \mathrm{~g}$ dry SCB solids (w/w), and 15 or 30 FPU cellulase $\mathrm{g}^{-1}$ pretreated dry SCB. Deionized water was added to each flask to make the total mass in each flask $100 \mathrm{~g}$.

All flasks were incubated at $45^{\circ} \mathrm{C}$ on an orbital shaker. The SSFs with $15 \%$ dry solids loading contained stainless steel balls (10 $\mathrm{mm}$ diameter) to assist in the dissolution of the SCB (Ramachandriya et al., 2013). Aliquots of $1.5 \mathrm{~mL}$ were collected at $0,7,24,48,72,96,120,144$, and $168 \mathrm{~h}$. The samples were centrifuged at $16,600 \times g$ for $10 \mathrm{~min}$ (AccuSpin Micro 17, Fisher Scientific, Pittsburgh, Pa.), and the supernatant was filtered through $0.45 \mu \mathrm{m}$ nylon syringe filters (VWR International, West Chester, $\mathrm{Pa}$.) and frozen until analyzed. At the end of each fermentation cycle, the $\mathrm{pH}$ values of all fermentation slurries were recorded. All SSF experiments were carried out in triplicate.

\section{ANALYSIS OF SSF SAMPLES BY HPLC}

The concentrations of glucose, xylose, galacturonic acid, acetic acid, and ethanol were measured by HPLC. Ten $\mu \mathrm{L}$ of each sample were analyzed by HPLC using an Aminex HPX-87H column (BioRad, Hercules, Cal.) with a refrac- tive index detector (RID) (Agilent 1100 Series, Santa Clara, Cal.). The mobile phase was $0.01 \mathrm{~N} \mathrm{H}_{2} \mathrm{SO}_{4}$ flowing at $0.6 \mathrm{~mL} \mathrm{~min}^{-1}$ at $60^{\circ} \mathrm{C}$ for $30 \mathrm{~min}$.

\section{Calculations}

The theoretical yield of ethanol was calculated using the following equation (Ramachandriya et al., 2014):

Theoretical yield $(\%)=\frac{\left[\mathrm{EtOH}_{t}\right]-\left[\mathrm{EtOH}_{0}\right]}{0.51 \cdot(f \cdot[\text { biomass }] \cdot 1.11)} \cdot 100$

where

$\left[\mathrm{EtOH}_{t}\right]=$ ethanol concentration $\left(\mathrm{g} \mathrm{L}^{-1}\right)$ produced at time $t(\mathrm{~h})$

$\left[\mathrm{EtOH}_{0}\right]=$ initial ethanol concentration $\left(\mathrm{g} \mathrm{L}^{-1}\right)$

$0.51=$ mass conversion factor of glucose to ethanol $\left(\mathrm{g} \mathrm{g}^{-1}\right)$

$f=$ glucan fraction of dry biomass (-)

[biomass] $=$ initial concentration of solids $\left(\mathrm{g} \mathrm{L}^{-1}\right)$

$1.11=$ conversion factor for glucan to glucose.

\section{RESULTS AND DISCUSSION SCB COMPOSITION}

Native SCB was subjected to extraction by ethanolwater prior to compositional analysis. The extraction of SCB resulted in the removal of $5.9 \%$ of the dry biomass as extractives, $1.7 \%$ by ethanol and $4.2 \%$ by water. The composition of SCB before and after pretreatment is shown in table 1 . The total dry native SCB contained $41.7 \%$ glucan, $22.3 \%$ xylan, $1.8 \%$ galactan, $2.6 \%$ arabinan, $0.5 \%$ mannan, $20.7 \%$ lignin, $4.3 \%$ ash, and $5.9 \%$ of extractives. The mass balance of compositional analysis accounted for $99.8 \%$ of dry matter in the SCB. These results are in agreement with data reported for native SCB (Rocha et al., 2011; Wanderley et al., 2013).

The recovery of SCB solids in the water-insoluble solids (WIS) remaining after pretreatment was $62.0 \%$. Hydrothermolysis resulted in $97.8 \%$ recovery of glucan and $10.3 \%$ recovery of xylan from the raw SCB in the WIS. Most of the lignin $(90.1 \%)$ from the raw SCB remained in the WIS. The WIS contained $65.8 \%$ glucan, $3.7 \%$ xylan, and $30.1 \%$ lignin. Oliveira et al. (2014) observed similar behavior for sugarcane straw using hydrothermolysis $\left(195^{\circ} \mathrm{C}\right.$ for $\left.10 \mathrm{~min}\right)$. Those authors reported an increase in glucan content from $38.1 \%$ to $62.6 \%$ and a decrease in xylan content from $29.2 \%$ to $3.5 \%$. Sugars quantified in the prehydrolysate, which is the liquid collected after pretreatment before washing, were

Table 1. Compositional analysis of native and hydrothermolyzed SCB.

\begin{tabular}{ccc}
\hline & $\begin{array}{c}\text { Native SCB } \\
(\% \text { d.b. })^{[\mathrm{a}]}\end{array}$ & $\begin{array}{c}\text { Hydrothermolyzed } \\
\text { SCB (\% d.b. })^{[\mathrm{a}]}\end{array}$ \\
\hline Components & $41.7 \pm 0.1$ & $65.8 \pm 1.5$ \\
Xlucan & $22.3 \pm 0.3$ & $3.7 \pm 0.6$ \\
Galactan & $1.8 \pm 0.1$ & - \\
Arabinan & $2.6 \pm 0.4$ & $0.1 \pm 0.1$ \\
Mannan & $0.5 \pm 0.1$ & $0.1 \pm 0.2$ \\
Lignin & $20.7 \pm 0.3$ & $30.1 \pm 1.3$ \\
Ash & $4.3 \pm 0.7$ & $\mathrm{ND}^{[\mathrm{b}]}$ \\
Extractives & $5.9^{[\mathrm{c}]}$ & $\mathrm{ND}^{[\mathrm{b}]}$ \\
\hline
\end{tabular}

\footnotetext{
a] d.b. $=$ dry basis.

[b] $\mathrm{ND}=$ not determined

[c] no replicates.
} 
$3.3 \mathrm{~g} \mathrm{~L}^{-1}$ glucose, $13.8 \mathrm{~g} \mathrm{~L}^{-1}$ xylose, $1.0 \mathrm{~g} \mathrm{~L}^{-1}$ galactose, $3.4 \mathrm{~g}$ $\mathrm{L}^{-1}$ arabinose, and $2.2 \mathrm{~g} \mathrm{~L}^{-1}$ mannose.

\section{SimULTANEOUS SACCHARIFICATION AND FERMENTATION}

Pretreated SCB was used as substrate for ethanol production. Figure 1a shows the time course of glucose con- centration in the SSFs. SSFs were performed at $10 \%$ $(\mathrm{w} / \mathrm{w}) / 15 \mathrm{FPU}, 10 \%(\mathrm{w} / \mathrm{w}) / 30 \mathrm{FPU}, 15 \%(\mathrm{w} / \mathrm{w}) / 15 \mathrm{FPU}$, and $15 \%(\mathrm{w} / \mathrm{w}) / 30$ FPU. Glucose concentration increased from 0 to $7 \mathrm{~h}$ as glucose was produced at a faster rate than the yeast could consume it. Glucose then decreased between 7 and $24 \mathrm{~h}$ for all treatments. Glucose was $2.1 \mathrm{~g} \mathrm{~L}^{-1}$ at $24 \mathrm{~h}$ for all flasks except the $10 \%(\mathrm{w} / \mathrm{w}) / 30 \mathrm{FPU}$ treat-

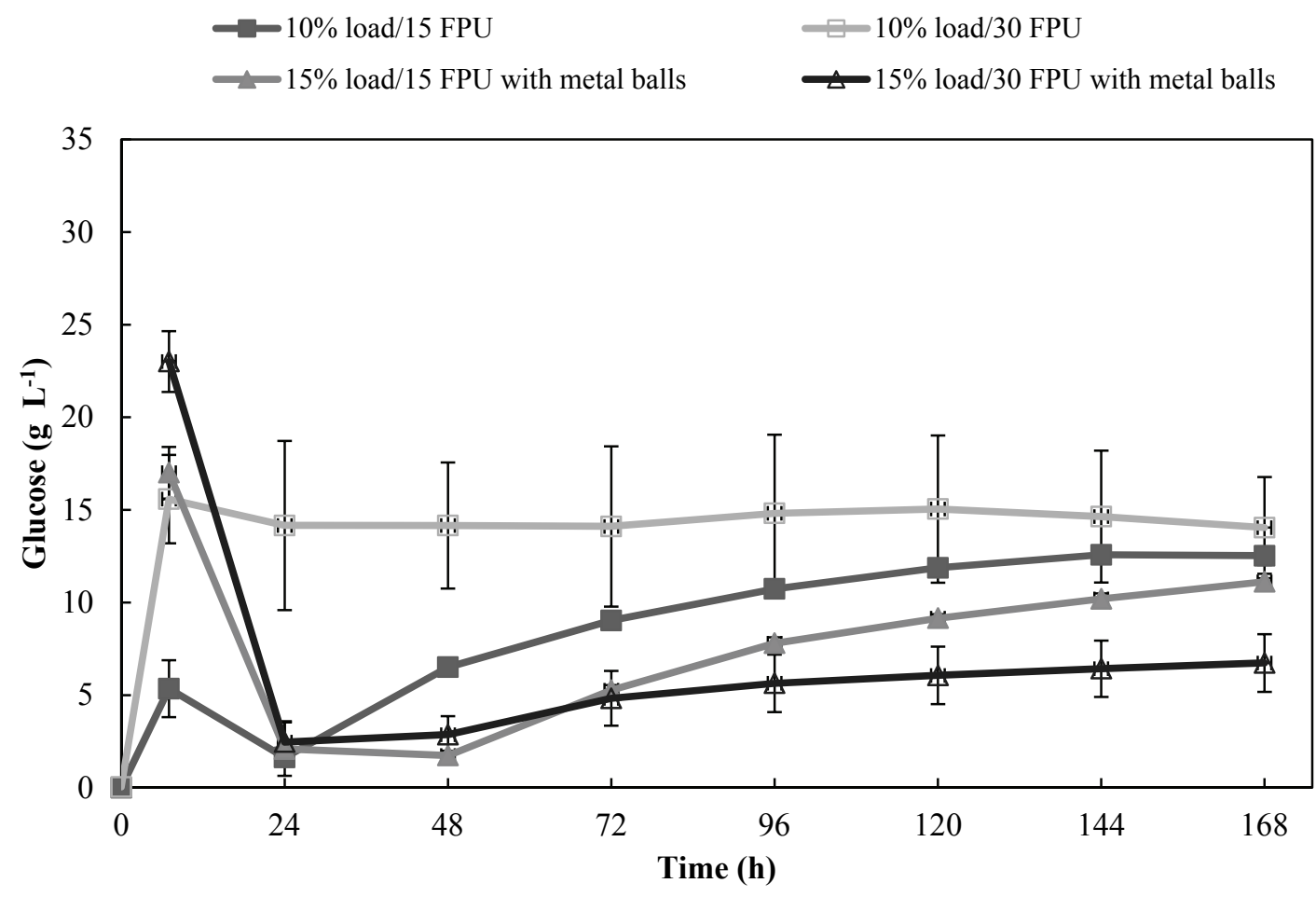

(a)

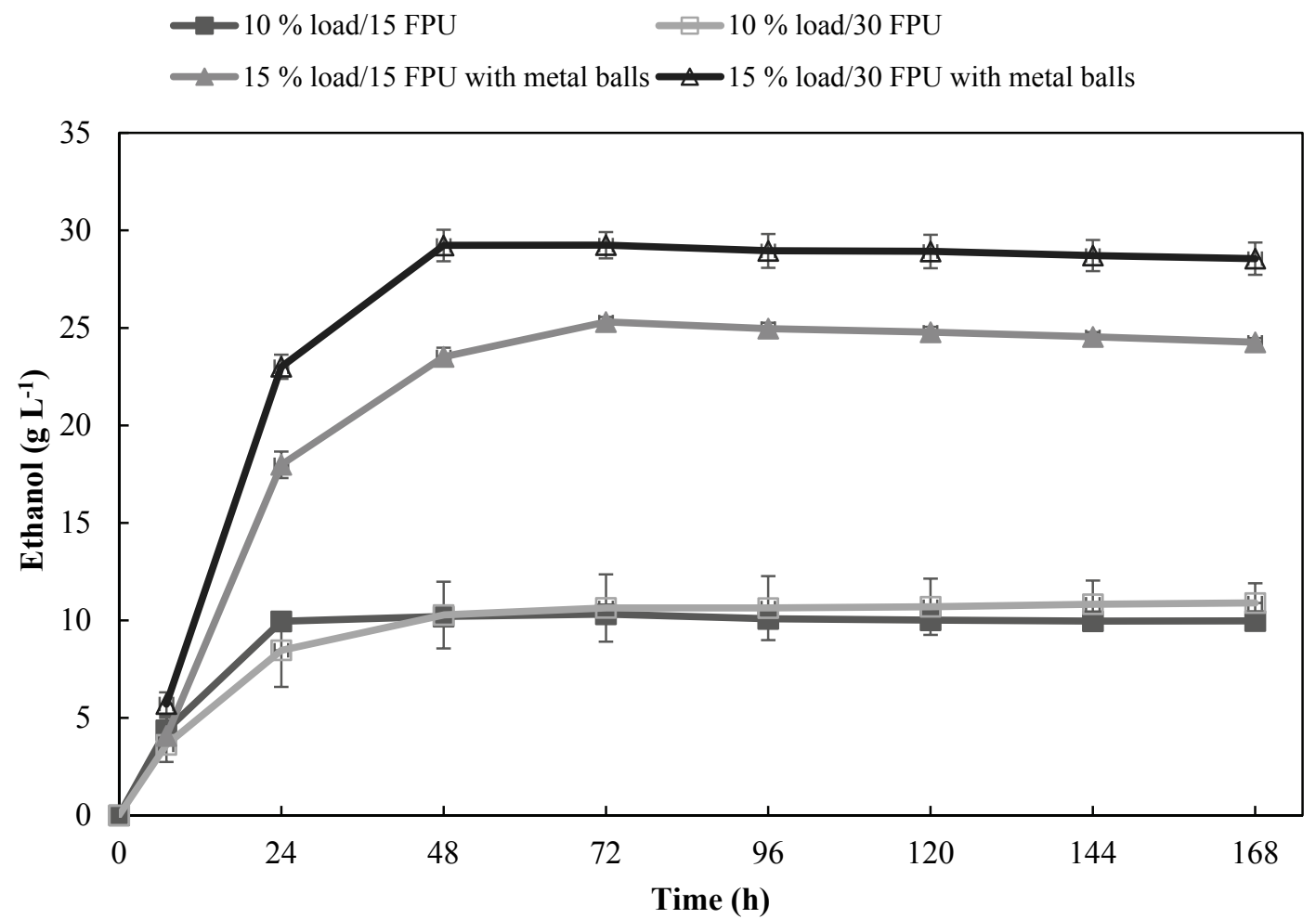

(b)

Figure 1. Concentrations of (a) glucose and (b) ethanol for $168 \mathrm{~h}$ during SSFs using $K$. marxianus IMB3 at $45^{\circ} \mathrm{C}$ with pretreated SCB. 
ment. The $10 \%(\mathrm{w} / \mathrm{w}) / 30$ FPU treatment had greater glucose concentrations than all other treatments throughout the SSFs, averaging $14.2 \mathrm{~g} \mathrm{~L}^{-1}$. The $15 \%(\mathrm{w} / \mathrm{w}) / 30 \mathrm{FPU}$ treatment had the lowest glucose concentration at the end of $\mathrm{SSF}$, with $6.7 \mathrm{~g} \mathrm{~L}^{-1}$, while the other treatments had glucose concentrations of $11.1 \mathrm{~g} \mathrm{~L}^{-1}$ or greater.

Ethanol concentrations in all SSF treatments are shown in figure $1 \mathrm{~b}$. All ethanol concentrations increased during the initial $7 \mathrm{~h}$, which indicated that enzymatic hydrolysis of glucan to glucose and ethanol fermentation occurred early in SSF. Production of ethanol continued in all treatments until $48 \mathrm{~h}$, after which ethanol concentration stabilized. The stable ethanol concentration corresponded with an increase in glucose concentration as the cellulase enzyme continued to hydrolyze cellulose to glucose. At $72 \mathrm{~h}$, ethanol concentrations were 10.3, 10.6, 25.3, and $29.2 \mathrm{~g} \mathrm{~L}^{-1}$ for the treatments $10 \%(\mathrm{w} / \mathrm{w}) / 15$ FPU, $10 \%(\mathrm{w} / \mathrm{w}) / 30$ FPU, $15 \%$ $(\mathrm{w} / \mathrm{w}) / 15 \mathrm{FPU}$, and $15 \%(\mathrm{w} / \mathrm{w}) / 30 \mathrm{FPU}$, respectively. After $72 \mathrm{~h}$, ethanol concentration did not increase in any treatment, which suggested that the cells were inhibited. The causes for inhibition of fermentation are not known; however, some authors have reported the combination of high temperature and low ethanol tolerance at $45^{\circ} \mathrm{C}$ as a major cause for low cell viability for K. marxianus IMB3 at $72 \mathrm{~h}$ (Pessani et al., 2011; Suryawati et al., 2009). Ballesteros et al. (2004) used $K$. marxianus CECT 10875 at $42^{\circ} \mathrm{C}$ in SSF and reported that ethanol production ceased between 72 and $82 \mathrm{~h}$, which they attributed to metabolic stress caused by low glucose concentration and the presence of ethanol in the SSF process. Suryawati et al. (2008) observed similar performance using $K$. marxianus IMB4 at $45^{\circ} \mathrm{C}$ and suggested that the combination of higher temperature, ethanol concentration, and decreased $\mathrm{pH}$ from acetic acid formation may have contributed to the cessation of fermentation.
Acetic acid production was observed during all SSFs. The profiles for acetic acid over time are shown in figure 2 . The maximum acetic acid concentration obtained was $2.6 \mathrm{~g}$ $\mathrm{L}^{-1}$ in the $15 \%(\mathrm{w} / \mathrm{w}) / 30 \mathrm{FPU}$ SSF after $168 \mathrm{~h}$. Acetic acid concentrations at $72 \mathrm{~h}$ were $1.0,1.3,2.0$, and $2.2 \mathrm{~g} \mathrm{~L}^{-1}$ in the $10 \%(\mathrm{w} / \mathrm{w}) / 15 \mathrm{FPU}, 10 \%(\mathrm{w} / \mathrm{w}) / 30 \mathrm{FPU}, 15 \%(\mathrm{w} / \mathrm{w}) / 15$ FPU, and 15\% (w/w)/30 FPU, respectively. Acetic acid formation during SSF can inhibit yeast growth. The lowest concentration of acetic acid $\left(1.2 \mathrm{~g} \mathrm{~L}^{-1}\right)$ was detected in the $10 \%$ load/15 FPU SSF after $168 \mathrm{~h}$. Pessani et al. (2011) reported that the increase in acetic acid concentration during SSFs was mainly due to $K$. marxianus IMB3 metabolic activity and not from the enzymatic hydrolysis of hemicelluloses. In these experiments, it was observed that higher ethanol concentration was associated with higher acetic acid concentrations, which is similar to that observed by Pessani et al. (2011). After $96 \mathrm{~h}$, acetic acid slightly increased in all SSFs. Suryawati et al. (2008) observed a similar behavior in SSF experiments using $K$. marxianus IMB4 at $45^{\circ} \mathrm{C}$. According those authors, acetic acid produced by IMB4 may have cause inhibition of IMB4 fermentation and ethanol production. A similar result was observed by Ballesteros et al. (2004) in SSF experiments using K. marxianus CECT 10875 at $42^{\circ} \mathrm{C}$.

In the final SSF experiments, the measured $\mathrm{pH}$ values were 5.03, 5.00, 4.85, and 5.01 for $10 \%(\mathrm{w} / \mathrm{w}) / 15 \mathrm{FPU}$, $10 \%(\mathrm{w} / \mathrm{w}) / 30$ FPU, $15 \%(\mathrm{w} / \mathrm{w}) / 15 \quad \mathrm{FPU}$, and $15 \%$ $(\mathrm{w} / \mathrm{w}) / 30 \mathrm{FPU}$, respectively. In this study, all the assays showed $\mathrm{pH}$ values of about 5.0. In this condition, the acetic acid was present in dissociated form. According to Oliva et al. (2003), dissociated acetic acid has little toxicity for cells and has an insignificant effect on ethanol yield. The undissociated form of acetic acid has been shown to have a greater inhibition of cellular growth than the dissociated

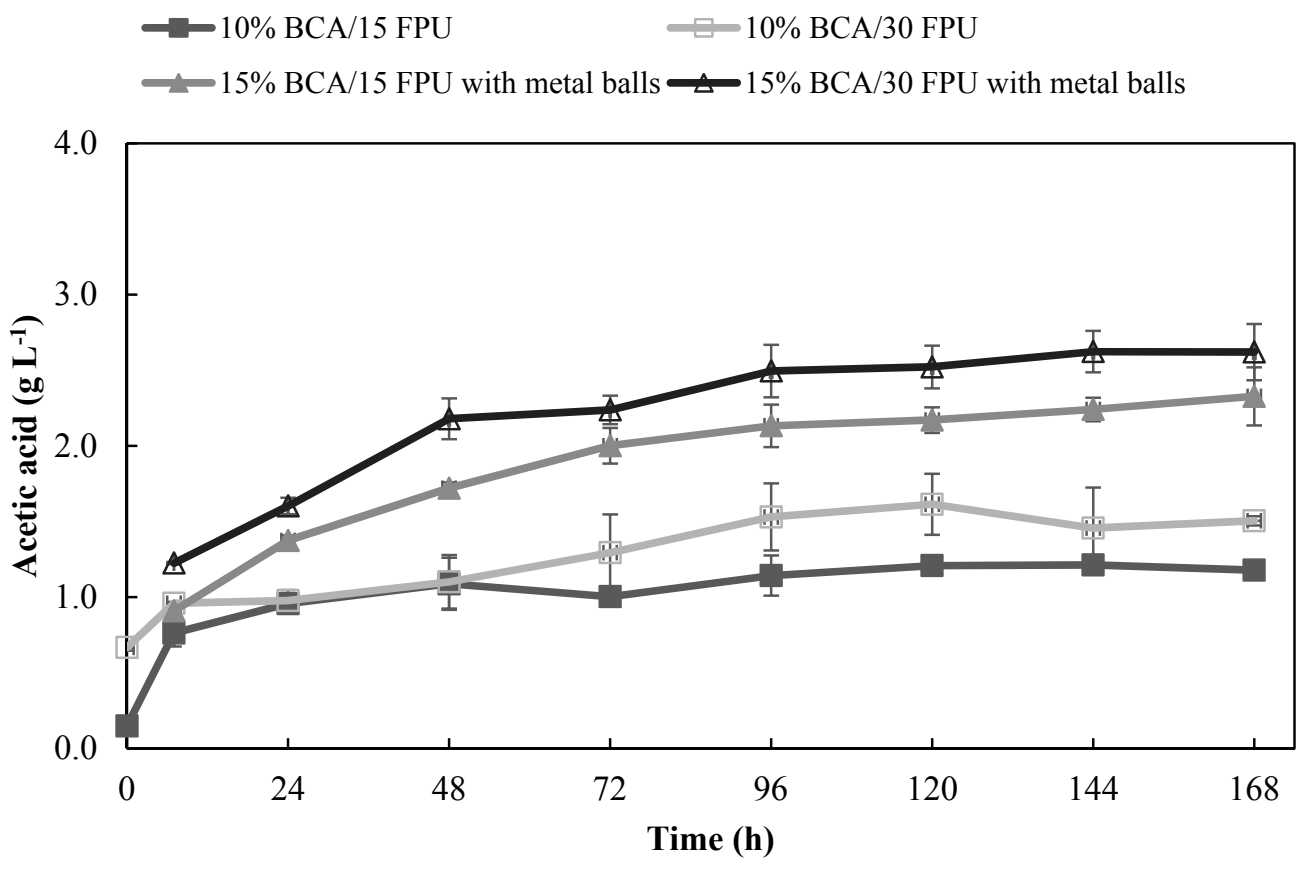

Figure 2. Acetic acid profiles in SSFs using $K$. marxianus IMB3 at $45^{\circ} \mathrm{C}$. 
Table 2. Summary of simultaneous saccharification and fermentation (SSF) assays with $K$. marxianus IMB3 at 48 h.

\begin{tabular}{|c|c|c|c|c|c|c|c|}
\hline $\begin{array}{c}\text { \% Solids } \\
\text { Loading } \\
(w / w)\end{array}$ & $\begin{array}{c}\text { Enzymatic } \\
\text { Loading } \\
\text { (FPU g }{ }^{-1} \text { glucan) }\end{array}$ & $\begin{array}{l}\% \text { Glucose } \\
\text { Conversion }\end{array}$ & $\begin{array}{c}\text { Ethanol } \\
\left(\mathrm{g} \mathrm{L}^{-1}\right)\end{array}$ & $\begin{array}{l}Y_{E / E t^{[\mathrm{a}]}} \\
\mathbf{( \% )}\end{array}$ & $\begin{array}{l}\% \text { Ethanol } \\
\text { from SSF } \\
\text { [b] }\end{array}$ & $\begin{array}{c}Q_{E}^{{ }_{E}^{[\mathrm{cl}}} \\
\left(\mathrm{g} \mathrm{L}^{-1} \mathrm{~h}^{-1}\right)\end{array}$ & $\begin{array}{c}P_{E}^{[\mathrm{d}]} \\
\left(\mathrm{mg} \mathrm{L}^{-1} \mathrm{FPU}^{-1} \mathrm{~h}^{-1}\right)\end{array}$ \\
\hline 10 & 15 & 46.1 & 10.3 & 31.2 & 67.9 & 0.20 & 14.3 \\
\hline 10 & 30 & 55.3 & 10.6 & 33.8 & 58.2 & 0.20 & 7.4 \\
\hline 15 & 15 & 56.9 & 25.3 & 48.1 & 89.9 & 0.46 & 35.1 \\
\hline 15 & 30 & 64.3 & 29.2 & 58.9 & 91.8 & 0.58 & 20.3 \\
\hline
\end{tabular}

[a] $Y_{E / E t}=$ theoretical ethanol yield assuming ethanol yields on glucose of $0.51 \mathrm{~g} \mathrm{~g}^{-1}$.

[b] $\%$ Ethanol from SSF = ethanol yield based on total glucose released in the SSF (total glucose present in SSF to ethanol).

[c] $Q_{E}=$ volumetric ethanol productivity.

[d] $P_{E}=$ specific ethanol productivity (ethanol concentration, $\mathrm{mg} \mathrm{L}^{-1}$ ) related enzymatic loading (FPU).

form (Berg et al., 2007). The $\mathrm{pH}$ of the media was greater than the pKa of acetic acid (4.8); thus, acetic acid was dissociated and had little effect on the cells during SSF.

Data obtained in the SSFs are summarized in table 2. Glucose conversion was $64.3 \%$ of the maximum theoretical possible in the fermentation with $15 \%(\mathrm{w} / \mathrm{w}) / 30 \mathrm{FPU}$. Glucose conversions were similar for the $10 \%(\mathrm{w} / \mathrm{w}) / 30 \mathrm{FPU}$ and $15 \%(\mathrm{w} / \mathrm{w}) / 15 \mathrm{FPU}$ treatments $(55.3 \%$ and $56.9 \%$, respectively). A comparison between treatments at $10 \%$ dry solids loading $(\mathrm{w} / \mathrm{w})$ showed that the $72 \mathrm{~h}$ ethanol concentration was about $10.0 \mathrm{~g} \mathrm{~L}^{-1}$ for both enzyme loadings; however, glucose conversion was $55.3 \%$ using $30 \mathrm{FPU}$ and $46.1 \%$ using $15 \mathrm{FPU}$, an increase of $16.6 \%$ in glucan conversion to glucose.

Theoretical ethanol yields, calculated by equation 1 , were $31.2 \%, 33.8 \%, 48.1 \%$, and $58.9 \%$ in the $10 \%$ (w/w)/15 FPU, 10\% (w/w)/30 FPU, 15\% (w/w)/15 FPU, and $15 \%(\mathrm{w} / \mathrm{w}) / 30 \mathrm{FPU}$ treatments, respectively. These low ethanol yields may be related to lower enzyme loadings, as compared to other studies that also used Accellerase enzymes (Pessani et al., 2011; Pryor and Nahar, 2010). For $10 \%(\mathrm{w} / \mathrm{w}) / 15 \mathrm{FPU}$ and $10 \%(\mathrm{w} / \mathrm{w}) / 30 \mathrm{FPU}$, an effect of enzymatic loading was not observed. The ethanol yields obtained from total glucose released in the SSFs were $91.8 \%, 89.9 \%, 67.9 \%$, and $58.2 \%$ for $15 \%(\mathrm{w} / \mathrm{w}) / 30 \mathrm{FPU}$, $15 \%(\mathrm{w} / \mathrm{w}) / 15$ FPU, $10 \%(\mathrm{w} / \mathrm{w}) / 15 \quad \mathrm{FPU}$, and $10 \%$ $(\mathrm{w} / \mathrm{w}) / 30 \mathrm{FPU}$, respectively. The results of $91.8 \%$ for $15 \%$ $(\mathrm{w} / \mathrm{w}) / 30 \mathrm{FPU}$ and $89.9 \%$ for $15 \%(\mathrm{w} / \mathrm{w}) / 15 \mathrm{FPU}$ enhance the hypothesis that \% maximum theoretical ethanol yields lower than those of other studies were due to slow enzyme hydrolysis and not due to poor yeast fermentation.

The volumetric ethanol productivity $\left(Q_{E}\right)$ at $72 \mathrm{~h}$ increased from 0.20 to $0.58 \mathrm{~g} \mathrm{~L}^{-1} \mathrm{~h}^{-1}$ when solids content and enzyme loading increased. The results showed that the highest $Q_{E}\left(0.58 \mathrm{~g} \mathrm{~L}^{-1} \mathrm{~h}^{-1}\right)$ resulted in the greatest ethanol concentration of $29.2 \mathrm{~g} \mathrm{~L}^{-1}$. However, specific ethanol productivity was $35.1 \mathrm{mg} \mathrm{L}^{-1} \mathrm{FPU}^{-1} \mathrm{~h}^{-1}$ for $15 \%(\mathrm{w} / \mathrm{w}) / 15$ FPU, which was $42.4 \%$ higher than the productivity obtained for $15 \%(\mathrm{w} / \mathrm{w}) / 30 \mathrm{FPU}\left(20.3 \mathrm{mg} \mathrm{L}^{-1} \mathrm{FPU}^{-1} \mathrm{~h}^{-1}\right)$. These results show that, in terms of ethanol produced per enzyme activity added, the best condition was $15 \%$ $(\mathrm{w} / \mathrm{w}) / 15 \mathrm{FPU}$.

\section{CONCLUSION}

This study showed that hydrothermolysis of SCB at $195^{\circ} \mathrm{C}$ for $10 \mathrm{~min}$ had $97.8 \%$ recovery of glucan and $89.4 \%$ removal of xylan in the WIS. The greatest ethanol concen- tration achieved from SSF using $K$. marxianus IMB3 after $72 \mathrm{~h}$ at $45^{\circ} \mathrm{C}$ was $29.2 \mathrm{~g} \mathrm{~L}^{-1}$ in the treatment containing $15 \%(\mathrm{w} / \mathrm{w}) / 30 \mathrm{FPU}$ of cellulase. This represented a yield of $58.9 \%$ of the maximum based on the glucan present after pretreatment, but the yield was $91.8 \%$ of the maximum based on the glucose released during hydrolysis. After $72 \mathrm{~h}$, an accumulation of glucose was observed as a result of a cessation of ethanol production. A possible cause of the cessation was the high temperature and ethanol stress of the yeast. When considering the ethanol productivity per FPU of cellulase activity, the $15 \%(\mathrm{w} / \mathrm{w}) / 15$ FPU treatment resulted in the greatest productivity of $35.1 \mathrm{mg}$ ethanol L ${ }^{-1}$ FPU $^{-1} h^{-1}$ at $48 \mathrm{~h}$.

\section{ACKNOWLEDGEMENTS}

This work has been supported by Coordenação de Aperfeiçoamento de Pessoal de Nível Superior (CAPES), Fundação de Amparo à Pesquisa do Estado de São Paulo (FAPESP), and the Oklahoma Agricultural Experiment Station. We thank Dr. Nurhan Dunford of Oklahoma State University for providing access to extraction equipment for compositional analyses. Gislene Mota da Silva thanks CNPq (National Council for Scientific and Technological Development) for the doctoral scholarship.

\section{REFERENCES}

Ballesteros, M., Oliva, J. M., Negro, M. J., Manzanares, P., \& Ballesteros, I. (2004). Ethanol from lignocellulosic materials by a simultaneous saccharification and fermentation process (SFS) with Kluyveromyces marxianus CECT 10875. Proc. Biochem., 39(12), 1843-1848. http://dx.doi.org/10.1016/j.procbio.2003.09.011.

Banat, I. M., Nigam, P., \& Marchant, R. (1992). Isolation of thermotolerant, fermentative yeasts growing at $52^{\circ} \mathrm{C}$ and producing ethanol at $45^{\circ} \mathrm{C}$ and $50^{\circ} \mathrm{C}$. World J. Microbiol. Biotech., 8(3), 259-263. http://dx.doi.org/10.1007/BF01201874.

Barron, N., Marchant, R., McHale, L., \& McHale, A. P. (1995). Studies on the use of a thermotolerant strain of Kluyveromyces marxianus in simultaneous saccharification and ethanol formation from cellulose. Appl. Microbiol. Biotech., 43(3), 518520. http://dx.doi.org/10.1007/BF00218459.

Berg, J., Tymockzo, J., \& Stryer, L. (2007). Biochemistry. New York, N.Y.: W. H. Freeman.

CONAB. (2014). $4^{\circ}$ Levantamento cana-de-açúcar-safra 2013/2014. Brasília, Brazil: Companhia Nacional de Abastecimento. Retrieved from www.conab.gov.br.

da Silva, A. S. A., Inoue, H., Endo, T., Yano, S., \& Bon, E. P. S. (2010). Milling pretreatment of sugarcane bagasse and straw for enzymatic hydrolysis and ethanol fermentation. Bioresource Tech., 101(19), 7402-7409. 
http://dx.doi.org/10.1016/j.biortech.2010.05.008.

Faga, B. A., Wilkins, M. R., \& Banat, I. M. (2010). Ethanol production through simultaneous saccharification and fermentation of switchgrass using Saccharomyces cerevisiae $\mathrm{D}_{5} \mathrm{~A}$ and thermotolerant Kluyveromyces marxianus IMB strains. Bioresource Tech., 101(7), 2273-2279. http://dx.doi.org/10.1016/j.biortech.2009.11.001.

Fengel, D., \& Wegener, G. (1989). Wood: Chemistry Ultrastructure and Reactions. Berlin, Germany: Walter de Gruyter.

Garcia-Aparicio, M. P., Oliva, J. M., Manzanares, P., Ballesteros, M., Ballesteros, I., Gonzalez, A., \& Negro, M. J. (2011). Second-generation ethanol production from steam-exploded barley straw by Kluyveromyces marxianus CECT 10875. Fuel, 90(4), 1624-1630. http://dx.doi.org/10.1016/j.fuel.2010.10.052.

Ghose, T. K. (1987). Measurement of cellulase activities. Pure Appl. Chem., 59(2), 257-268. http://dx.doi.org/10.1351/pac198759020257.

Kadar, Z., Szengyel, Z., \& Reczey, K. (2004). Simultaneous saccharification and fermentation (SSF) of industrial wastes for the production of ethanol. Ind. Crops Prod., 20(1), 103-110. http://dx.doi.org/10.1016/j.indcrop.2003.12.015.

Moreno, A. D., Ibarra, D., Ballesteros, I., Gonzalez, A., \& Ballesteros, M. (2013). Comparing cell viability and ethanol fermentation of the thermotolerant yeast Kluyveromyces marxianus and Saccharomyces cerevisiae on steam-exploded biomass treated with laccase. Bioresource Tech., 135, 239-245. http://dx.doi.org/10.1016/j.biortech.2012.11.095.

Mosier, N., Wyman, C., Dale, B., Elander, R., Lee, Y., Holtzapple, M., \& Ladisch, M. (2005). Features of promising technologies for pretreatment of lignocellulosic biomass. Bioresource Tech., 96(6), 673-686. http://dx.doi.org/10.1016/j.biortech.2004.06.025.

Oliva, J. M., Saez, F., Ballesteros, I., Gonzalez, A., Negro, M. J., Manzanares, P., \& Ballesteros, M. (2003). Effect of lignocellulosic degradation compounds from steam explosion pretreatment on ethanol fermentation by thermotolerant yeast Kluyveromyces marxianus. Appl. Biochem. Biotech., 105(1-3), 141-153. http://dx.doi.org/10.1385/ABAB:105:1-3:141.

Oliveira, L. R. M., Nascimento, V. M., Gonçalves, A. R., \& Rocha, G. J. M. (2014). Combined process system for the production of bioethanol from sugarcane straw. Ind. Crops Prod., 58, 1-7.

Olofsson, K., Bertilsson, M., \& Lidén, G. (2008). A short review on SSF: An interesting process option for ethanol production from lignocellulosic feedstocks. Biotech. Biofuels, 1, http://dx.doi.org/ 10.1186/1754-6834-1-7.

Perez, J. A., Ballesteros, I., Ballesteros, M., Saez, F., Negro, M. J., \& Manzanares, P. (2008). Optimizing liquid hot water pretreatment conditions to enhance sugar recovery from wheat straw for fuel ethanol production. Fuel, 87(17-18), 3640-3647. http://dx.doi.org/10.1016/j.fuel.2008.06.009.

Pessani, N. K., Atiyeh, H. K., Wilkins, M. R., Bellmer, D. D., \& Banat, I. M. (2011). Simultaneous saccharification and fermentation of Kanlow switchgrass by thermotolerant Kluyveromyces marxianus IMB3: The effect of enzyme loading, temperature, and higher solid loadings. Bioresource Tech., 102(22), 10618-10624. http://dx.doi.org/10.1016/j.biortech.2011.09.011.

Pryor, S. W., \& Nahar, N. (2010). Deficiency of cellulase activity measurements for enzyme evaluation. Appl. Biochem. Biotech., 162(6), 1737-1750.

Ramachandriya, K. D., Wilkins, M., Atiyeh, H. K., Dunford, N. T., \& Hiziroglu, S. (2013). Effect of high dry solids loading on enzymatic hydrolysis of acid bisulfite pretreated eastern red cedar. Bioresource Tech., 147, 168-176.

http://dx.doi.org/10.1016/j.biortech.2013.08.048.

Ramachandriya, K. D., Wilkins, M., Pardo-Planas, O., Atiyeh, H.
K., Dunford, N. T., \& Hiziroglu, S. (2014). Simultaneous saccharification and fermentation of eastern red cedar heartwood and sapwood using a novel size reduction technique.

Bioresource Tech., 161, 1-9. http://dx.doi.org/10.1016/j.biortech.2014.03.005.

Rocha, G. J. D., Martin, C., Soares, I. B., Maior, A. M. S., Baudel, H. M., \& de Abreu, C. A. M. (2011). Dilute mixed-acid pretreatment of sugarcane bagasse for ethanol production. Biomass Bioenergy, 35(1), 663-670.

Rocha, G. J. M., Gonçalves, A. R., Oliveira, B. R., Olivares, E. G., \& Rossell, C. E. V. (2012). Steam explosion pretreatment reproduction and alkaline delignification reactions performed on a pilot scale with sugarcane bagasse for bioethanol production. Ind. Crops Prod., 35(1), 274-279.

http://dx.doi.org/10.1016/j.indcrop.2011.07.010.

Ruiz, H. A., Silva, D. P., Ruzene, D. S., Lima, L. F., Vicente, A. A., \& Teixeira, J. A. (2012). Bioethanol production from hydrothermal pretreated wheat straw by a flocculating Saccharomyces cerevisiae strain: Effect of process conditions. Fuel, 95(1), 528-536.

http://dx.doi.org/10.1016/j.fuel.2011.10.060.

Saha, B. C., Yoshida, T., Cotta, M. A., \& Sonomoto, K. (2013). Hydrothermal pretreatment and enzymatic saccharification of corn stover for efficient ethanol production. Ind. Crops Prod., 44, 367-372. http://dx.doi.org/10.1016/j.indcrop.2012.11.025.

Santos, J. R. A., Lucena, M. S., Gusmao, N. B., \& Gouveia, E. R. (2012). Optimization of ethanol production by Saccharomyces cerevisiae UFPEDA 1238 in simultaneous saccharification and fermentation of delignified sugarcane bagasse. Ind. Crops Prod., 36(1), 584-588. http://dx.doi.org/10.1016/j.indcrop.2011.10.002.

Silva, R., Haraguchi, S. K., Muniz, E. C., \& Rubira, A. F. (2009). Aplicações de fibras lignocelulósicas na química de polímeros e em compósitos. Química Nova, 32(3), 661-671. http://dx.doi.org/10.1590/S0100-40422009000300010.

Sluiter, A., Hames, B., Hyman, D., Payne, C., Ruiz, R., Scarlata, C., Sluiter, J., Templeton, D., \& Wolfe, J. (2008a). Determination of total solids in biomass and total dissolved solids in liquid process samples. Technical Report NREL/TP-510-42621. Golden, Colo.: National Renewable Energy Laboratory.

Sluiter, A., Hames, B., Ruiz, R., Scarlata, C., Sluiter, J., \& Templeton, D. (2008b). Determination of sugars, byproducts, and degradation products in liquid fraction process samples. Technical Report NREL/TP-510-42623. Golden, Colo.: National Renewable Energy Laboratory.

Sluiter, A., Ruiz, R., Scarlata, C., Sluiter, J., \& Templeton, D. (2008c). Technical Report NREL/TP-510-42619. Determination of extractives in biomass. Golden, Colo.: National Renewable Energy Laboratory.

Sluiter, A., Hames, B., Ruiz, R., Scarlata, C., Sluiter, J., Templeton, D., \& Crocker, D. (2011). Determination of structural carbohydrates and lignin in biomass. Technical Report NREL/TP-510-42618. Golden, Colo.: National Renewable Energy Laboratory.

Suryawati, L., Wilkins, M. R., Bellmer, D. D., Huhnke, R. L., Maness, N. O., \& Banat, I. M. (2008). Simultaneous saccharification and fermentation of Kanlow switchgrass pretreated by hydrothermolysis using Kluyveromyces marxianus IMB4. Biotech. Bioeng., 101(5), 894-902. http://dx.doi.org/10.1002/bit.21965.

Suryawati, L., Wilkins, M. R., Bellmer, D. D., Huhnke, R. L., Maness, N. O., \& Banat, I. M. (2009). Effect of hydrothermolysis process conditions on pretreated switchgrass composition and ethanol yield by SSF with Kluyveromyces marxianus IMB4. Proc. Biochem., 44(5), 540-545. http://dx.doi.org/10.1016/j.procbio.2009.01.011.

Trajano, H. L., Engle, N. L., Foston, M., Ragauskas, A. J., 
Tschaplinski, T. J., \& Wyman, C. E. (2013). The fate of lignin during hydrothermal pretreatment. Biotech. Biofuels, 6, 110. http://dx.doi.org/10.1186/1754-6834-6-110.

UNICA. (2012). Bioeletricidade: O que falta para esta alternativa energética deslanchar. Brasília, Brazil: União da Industria de Cana de Açucar. Retrieved from www.unica.com.br.

Wanderley, M. C. A., Martín, C., Rocha, G. J. M., \& Gouveia, E. R. (2013). Increase in ethanol production from sugarcane bagasse based on combined pretreatments and fed-batch enzymatic hydrolysis. Bioresource Tech., 128, 448-453.

Williams, A. G., \& Morrison, I. M. (1982). Studies on the production of saccharinic acids by the alkaline treatment of young grass and their effectiveness as substrates for mixed rumen microorganisms in vitro. J. Sci. Food Agric., 33(1), 2129. http://dx.doi.org/10.1002/jsfa.2740330106.

Wingren, A., Galbe, M., \& Zacchi, G. (2003). Techno-economic evaluation of producing ethanol from softwood: Comparison of SSF and SHF and identification of bottlenecks. Biotech.

Progress, 19(4), 1109-1117. http://dx.doi.org/10.1021/bp0340180.

Yu, Q., Zhuang, X. S., Lv, S. L., He, M. C., Zhang, Y., Yuan, Z. H., Qi, W., Wang, Q., Wang, W., Tan, X. S. (2013). Liquid hot water pretreatment of sugarcane bagasse and its comparison with chemical pretreatment methods for the sugar recovery and structural changes. Bioresource Tech., 129, 592-598. http://dx.doi.org/10.1016/j.biortech.2012.11.099. 